\title{
The role of ethno-regional parties in European integration. Is it a distractor or a catalyst?
}

\section{Introduction}

One of the concepts circulated in debates on the ultimate vision for European integration since the mid-1980s has been, in its essence, the strengthening of the role of the regions in this process. The aim was to empower European regions and supply them with more generous funding. Even in those early days, the initiative was criticized by advocates of preserving the strong position of nation-states in European integration. Their principal argument has been that the granting of greater autonomy to regions is bound to harm the national sovereignty of the member states. The article attempts to explore the extent to which ethno-regional parties, which have come to be associated with the rise of regionalist tendencies, weaken national states and indirectly strengthen the EU institutions (the European Commission and the European Parliament). To answer this question, one is compelled to examine Europe's ethno-regional parties, which have only recently attracted the interest of Polish political scientists and sociologists.

The author posits that ethno-regional parties have become a significant albeit not a determining theme in debates on the objectives of European integration. While advocates of federalism use such parties to demonstrate that strong European regions are the best possible future that the European Union can have, opponents of federalist ideas depict regions as an EU Trojan horse that threatens to destroy the very existence of nation-states from within. The parties' leaders find themselves conflicted between appreciating the legal and institutional capacities of the European Union, which allow them the freedom to pursue their aspirations with the Union's protection, and the urge to oppose the Union's bid to reduce the role of nation-states, which makes the EU an unlikely strategic partner for groupings that aspire to create their own states. A reasonable happy medium can be found by establishing territorial autonomy, as proposed by Jan Iwanek, serving as the middle ground between a territorial self-government and a federation. "Territorial autonomy today is about exercising public authority in a decentralized state either across that state's entire territory or across its substantial portion, in keeping with the principle of representation, with the authority to set up a local parliament and a government that answers thereto, and with constitutionallyprotected inalienable rights enshrined in Community legislation and implemented by an administration that reports to it" (Iwanek, 2014).

In Poland, the issue has acquired particular significance amidst the announcements that a regular ethno-regional party would be established in the Polish region of Upper Silesia (Górny Ślask), and the expectations that the party would mobilize and bring together Upper Silesian regionalists in the forthcoming municipal elections, capturing 
the electoral potential revealed by the 2011 National Population and Housing Census. Moreover, more research is needed into the future of Europe's regionalist movements as the opinion that they are losing momentum following the pan-European tendency of strengthening nation-states appears to be highly exaggerated.

\section{Impact of European migration processes on the redefinition of regionalism}

In the late 1980s, regionalist tendencies in Western Europe surged under the influence of many factors. Some of them were functional, associated with new ways to rally the public to engage in politics and a new definition of the social and economic significance of territory. In essence, the definition emphasized the role of territory as a basis for processes previously viewed from the perspective of nation-states. Therefore, unlike on previous occasions when the change was limited to state policies, it now extended to changing international markets and the emerging new West European order. It was no longer possible to pursue regional policy by relying on the old mechanisms of territorial regulation and exchange, nor was it as easy as previously to adjust the policy to existing land use management practices. The state has changed and, in the process, lost its ability to manage spatial transformations and spatial development. The power and authority of the state decayed at multiple levels. One of these levels, which is the topmost, was the internationalization of social, cultural, economic (globalization) and political processes. Another, arising in response to developments at the previous level, were new aspirations and demands formulated by regional and local communities. This second level tied directly to a third, which was the rise in power of and the pressures exerted by "civil society", with all of its many influences. As a result, these factors brought about a degradation of the prerogatives of the state in the fields of economic governance, social solidarity, culture and identity formation, as well as institutional structure. This gave rise to processes which Michael Keating collectively referred to as the "new regionalism." Characterized by conjoined features, "[t]his regionalism goes beyond the framework of the nation-state; and it pits regions against each other in a competitive mode, rather than providing complementary roles for them in a national division of labour. The new regionalism is modernizing and forward-looking, in contrast to an older provincialism, which represented resistance to change and defence of tradition. Yet both old and new regionalism continue to coexist in uneasy partnership, seeking a new synthesis of the universal and the particular" (Keating, 1998, p. 73).

While the new regionalism is partly a spin-off of European integration, the question that arose is how exactly it is going to impact the process. The ideas raised in related debates cover a very wide spectrum. Urs Altermatt, a Swiss scholar specializing in modern history, argued that "European integration and regional movements are part of a single whole. Regionalists are known for their fondness for the European community in the expectation that Brussels will support their resistance to the centrist leanings of nation-states [...] Political integration, as seen in the European Union, leads to differentiation at the lowest levels of the political spectrum. The model of a homogeneous culture reminiscent of nineteenth-century nationalism appears to have no future in the 
late twentieth century. As members of modern societies grow increasingly interdependent in technical, economic, and political terms on the one hand, and in cultural and political terms on the other, one's origin has lost most of its significance for people's living conditions. This, in turn, causes the classic state to experience difficult times in Western Europe" (Altermatt, 1998, pp. 227-228). Although Altermatt's conclusion seemed to be slightly over the top even in the late the $20^{\text {th }}$ century, the future of the integration project looked a great deal brighter at the turn of the century. The prospect of a qualitative leap through the enlargement of the European Union appeared to be well within grasp. Hitherto, the enlargement had been limited to the same collection of Western European countries. With every acceding country, the European Union saw its economic and political power grow stronger. "Eastern enlargement," as the addition of Central and Eastern Europe to the Union was called, remained a big unknown. On the one hand, to use a metaphor coined by Pope John Paul II, Europe was recovering its "second lung," albeit amidst fears that the problems Europe experienced with this part of the Continent throughout the $20^{\text {th }}$ century, would persist. However, the political and economic condition of the European Union and the new millennium enthusiasm drove European politicians, often in spite of anxieties rampant in their societies, to press ahead boldly. On May 1, 2004, the Union admitted 10 states, most of which had remained in a different world in terms of politics, ideology, culture and, above all, economy, until 1989. Obviously, the cost of the enlargement would have to be carried by the "old" member states. At that time, voices were also heard that were less enthusiastic about the consequences of the enlargement on the functioning of the European Union. Part of the reason was that the ethnic and national conflicts in this part of the continent, which were placed in deep freeze by Europe's division in Yalta by the antiNazi alliance, were "unfrozen" in 1989. This revived the fears that Europe would again become the site of ethnic conflicts rooted in ethnic nationalism. Such fears seemed to be justified after the experience of the Balkan wars in the late $20^{\text {th }}$ century. Wawrzyniec Konarski explicitly stated it was a peculiar paradox of modernity that ethnic rather than political nationalism ${ }^{1}$ is currently dominant in Europe. Most importantly, both the eastern and western parts of the Continent are facing the problem. Konarski argues that although the emergence of ethnic nationalism in the countries of the European Union "does not constitute a direct roadblock to political, legal and economic harmonization, it nevertheless reveals that dissenting opinions on such issues exist, shared by their numerous nationals. Such differences arise not only from misgivings about the status

${ }^{1}$ The distinction between ethnic and political nationalism has been brought into the political debate by Hans Kohn, who defined nationalism as "... a state of mind in which an individual's first loyalty is toward the nation-state." Wawrzyniec Konarski combines the concept of Carleton Hayes, who views nationalism as "a combination of patriotism and national awareness" with the concept of H. Kohn. He argues that the combination of these two approaches allows one to perceive nationalism as "two mutually antagonistic concepts: that of political nationalism and that of ethnic (or ethniclinguistic) nationalism. [...] The former, derived from the theory of national sovereignty, links up to the development of democracy and is labeled 'western'. Ethnic nationalism, in its turn, referred to as 'eastern', is considered to be a product of backwardness, lacking democratic traditions and an inferiority complex [...]. Hence, nationalism in Central and Eastern Europe was portrayed as a narrow, ethnically exclusive and pejorative concept, while the western brand was seen as ethnically open and semantically neutral, i.e. ethnically inclusive" (Konarski, 2012, pp. 72-73). 
of the nation-state in the so-called united Europe. The question is how Europe's unification will affect the cultural identity of communities that consider themselves to be national minorities or nations that are aware of their distinct nature. [...] These smaller nations and/or minorities try to exploit the apparent weakening of nation-states, to achieve their political objectives" (Konarski, 2012, p. 87). Initially, regionalism driven by "political nationalism" could be seen as a consequence of European integration, the pillars of which were the democratic processes used to resolve all disputes, including the self-determination-related rights of ethnic, national and linguistic groups. Due to the extent and severity of issues arising in connection with the functioning of these minorities, the accession to the EU by Central and Eastern European countries changed the treatment of regionalisms, and especially those of ethnic origin. Konarski states that although it is not possible to be entirely clear on where future regional movements are headed, they will need to answer the following three questions: "a. should they be satisfied with further concessions from the present national states (that nevertheless fall short of full sovereignty); b. should they demand that 'their' regions be annexed to kin states; or c. should they seek to create entirely new nation-states. The pursuit of the latter option would provide a new impetus for the idea of the nation-state, albeit at the expense of complicating if not entirely stopping the unification of Europe" (ibid.). The first fifteen years of the functioning of the sovereign states of the former Eastern Bloc saw the rise in aspirations to add legitimacy to their identity by applying ethnic criteria. It is therefore doubtful whether the new nation-states created on the back of regionalism would support projects designed in essence to weaken the sovereignty of nation-states. The resulting prospects for the perception of the future of this project by the EU member states are fairly bleak. Konarski notes this in his conclusions on the impact of regionalist movements on the future of European integration: "[...] regionalist movements may pose a predictable threat not only to those states [in which they occur - note by C.T.] but also to the very idea of a united Europe. The danger in the former case is somewhat closer than it is in the latter. One should additionally bear in mind that the face of such movements is primarily ethnic, as opposed to political or civic" (ibid., p. 88). One opportunity for regionalist movements to achieve the aspirations in a relatively stable way is to act while the political and economic foundations of both the member states and the European Union remain stable. It seems that the chances of having a conflict-free process are very slim at present.

To summarize the discussion on European regionalism, one should note that the process of regionalization has been incorporated into European integration and the axiological system of the Council of Europe, which is one of the key institutions aiming to "achieve a greater unity among its members for the purpose of safeguarding and realising the ideals and principles which are their common heritage and facilitating their economic and social progress" (Article 1 of the Statute of the Council of Europe). Although the Council is not an institution of the European Union, it is a key factor for the integration of European countries around a value system that nearly all countries on the Continent consider important. Just how important this institution really is has been demonstrated by the fact that almost all (47) countries of Europe other than Belarus, Kosovo and the Vatican, are its members. While the Council respects the sovereign right of the member states to determine their own political and economic 
systems, it does require that its members uphold the basic principles of democracy, which include the freedom to express one's identity. One of the ways of ensuring such freedom is to provide for territorial autonomy, which logically becomes "an instrument for the protection of the rights of such communities that promotes the preservation of identity, and the fulfillment of cultural and social aspirations. [...] Autonomy is not [...] a prerequisite for membership or a necessary constitutional form enforced in the institutional system of the CE. However, the Council requires that any identifiable community with such aspirations enjoy, within its region, the protection of its rights and guarantees of identity in accordance with the European Charter for Regional SelfGovernment" (Jaskiernia, p. 58). To some extent, territorial autonomy is the highest form of acceptance by a "nationalizing state"2 (Brubaker, 1998) of the aspirations of some of its citizens to express their distinctiveness. Regionalist movements in Europe frequently invoke this approach, quoting it as often as they come into conflict with the nation-state. To structure the discussion on regions in terms of values in the axiological system of the Council of Europe, basing it on the work of Jerzy Jaskiernia, one should point out that in this system, regionalism:

- results from the recognition that European societies are diverse, as in addition to geographical administrative regions, almost every European country has other divisions that run along historical, cultural, national, ethnic and linguistic lines;

- is an instrument used to reduce economic disparities among regions within countries of Europe;

- is a way to present regions as being subject to the European policy of subsidiarity by bringing the power to make decisions on the allocation of aid closer to the citizen;

- is an instrument used to articulate and consequently preserve the cultural identities of regional groups (ethnic, national, and linguistic minorities);

- is a way to keep in check the separatist tendencies that jeopardize the territorial integrity of the countries in which such aspirations are expressed;

- is a way to minimize the negative effects of globalization, especially in economic and cultural terms;

- is a factor for strengthening Europe's identity, regardless of which vision of the future of Europe prevails, whether it is the French concept of "Europe of homelands" or the German proposal to create federalist states - regionalization shifts the focus towards regions (Jaskiernia, pp. 49-55).

All of the values of today's European regionalism emanate directly from the European Charter of Local Self-Government, which in addition to the World-Wide Declaration of Local Self-Government, governs the status of local governments internationally. The preamble to that Charter emphasizes the importance of self-government for the construction of Europe. It points to democracy and the decentralization of power as the two guiding principles that underpin European integration. According to this document, "local legislative bodies: councils and assemblies should be appointed in

${ }^{2}$ In his description of the transformation Central and Eastern European states witnessed after 1989, Brubaker employs such terms as "external homeland," "nationalizing state" and "national minority." He refers to them in his study Nationalism Reframed. Nationhood and the national question in the New Europe, where Brubaker discusses the national and ethnic issues in the post-communist countries and in particular addresses the rebirth of nationalism after 1989 and its outcomes for Europe. 
universal, direct, equal, proportional and anonymous (secret ballot) elections. [...] The Charter views society as the central self-governing unit. The institutions themselves are of lesser importance - they are mere tools in the hands of local communities used to pursue common interests" (Marzęcka, 2012).

\section{Regional parties as a concept in political science}

As mentioned earlier, the late $20^{\text {th }}$ and early $21^{\text {st }}$ centuries have observed societies rallying around ethnic and national identities and influencing the formation of new states. Such rallying is evident in the transformations of party systems that, in their essence, lead to the emergence of new political parties that represent the political interests of various ethnic or national minorities. The most common expectation in this process is that such minorities will receive greater rights and that the region they inhabit will be given greater independence, if not complete autonomy (SobolewskaMyślik, 2012).

The most spectacular examples of the aspirations described by sociologists and political scientists in the context of regionalism are various social and political movements aiming to increase the autonomy of the region in which they operate, as well as movements seeking to preserve cultural differences by strengthening a sense of cultural identity in the inhabitants of individual regions. The purest form of maintaining such identity is to nourish the local language, which, after all, constitutes the most "tangible" example of cultural distinctiveness that a given community has at its disposal relative to the groups that surround it. Other regionalist activities are to nurture historical memories, and especially those of traumatic events, the goal being to bring a region's population together by highlighting the events that remind them how they have been wronged.

In institutional terms, such efforts lead to the formation and operation of various organizations, cultural societies, educational associations, sports clubs, choirs, museums and, finally, regional political parties. The reason the latter were the last to appear was that they were usually the ones that fueled the aspirations relative to the dominant group or the central government of the state to which the region in question belongs. The emergence of regional political parties becomes possible only after the degree of democratization of the relevant states allows it. It is therefore understandable why no such parties operated in Central and Eastern Europe prior to 1989. Neither did they appear immediately after the fall of the Berlin Wall, as the majority of the former Eastern Bloc countries were becoming increasingly nationalist. The societies of these countries used nationalist sentiments to vent the almost half a century's worth of pent-up frustrations that resulted from having the so-called "moral and political unity" imposed on them. ${ }^{3}$ This does not

${ }^{3}$ The term "moral and political unity" emerged as a social and political aim during the Stalin era. At the time, it was understood as the need to integrate society around an action, goal or idea. It was seen as the potential state to be pursued by mobilizing society and identifying those who stand in the way of its achievement, dismissed as "churls," "parasites" or "layabouts." In Poland, quite uniquely for a communist bloc country, the declared aim was to mobilize the nation (sic!) to fight against "enemies of socialism," who stood for reactionary forces. Communists viewed any social dispute or 
mean that these countries had no historical traditions to which regionalists could appeal. Regionalists took advantage of this opportunity as soon as the European Union enlarged to the East, forcing the respective countries to abide by EU laws.

It is commonly believed that Europe is home to more than a hundred regions whose aspiration to express their collective interests internationally is being suppressed (see Map 1). To illustrate this for the sake of a public debate, European regionalists employ the term "Europe of a hundred flags" (Geremek, 2003). The parties which, in their charters, speak of the need to represent these regions, are labeled as regional. In fact, national parties too present themselves in their electoral programs as determined to protect the interests of regional groups. However, they tend to forget their pledges as soon as they are elected, as activists from regions where identity aspirations run deep tend to concede to reluctant party members from other regions, who view such aspirations as a social, political and economic integrity risk for the entire state. That is precisely why Polish political research on regions focuses on local authorities. Although many political scientists who study party systems refer to regions in their research, they usually do so for methodological conformity rather than in the conviction that regional parties are indeed playing an ever more important role in competing for votes.

Map 1. The Europe of regions: languages, cultures, citizens - diversity

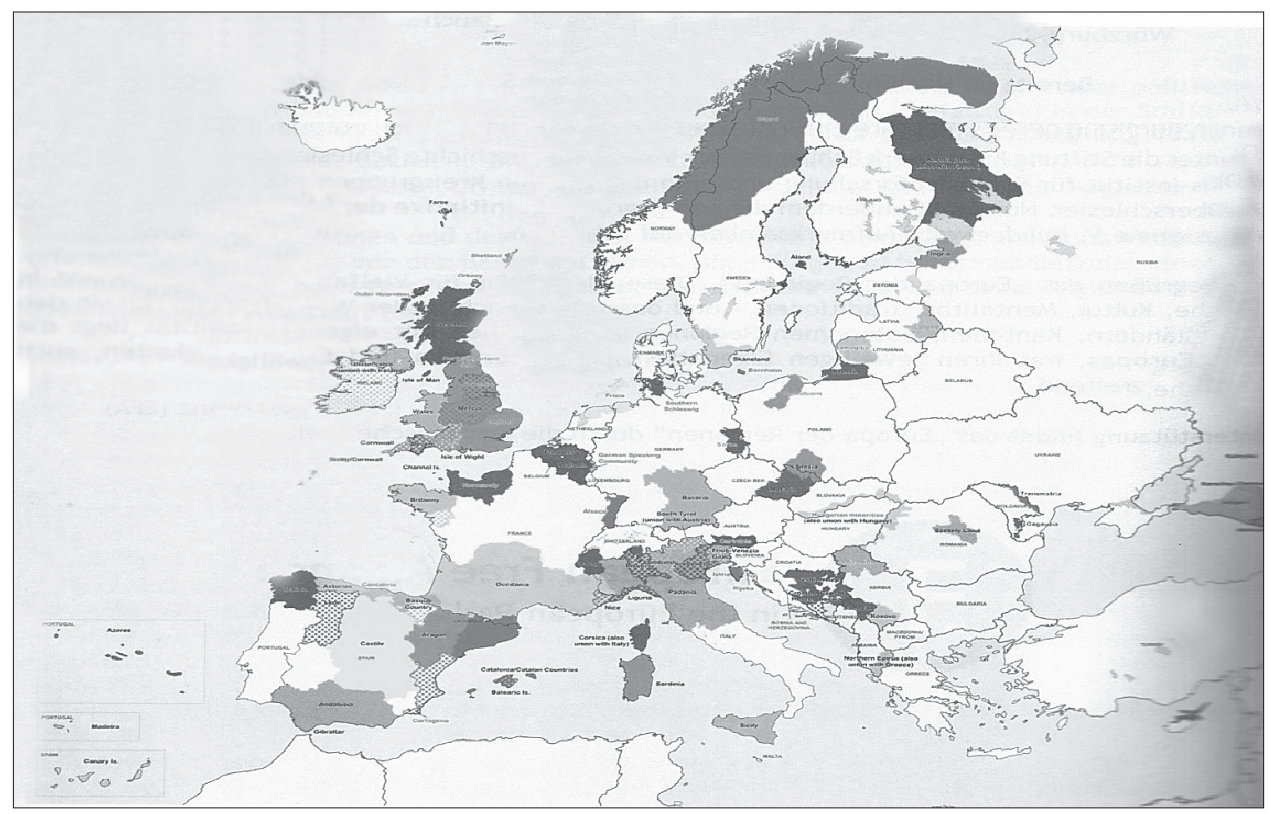

Source: Oberschlesien emanzipiert sich - mit oder ohne die Deutschen, IkAS e. V. und Verlag Inspiration Un Limited, London-Berlin, 2015, p. 122.

In her monograph (Myśliwiec, 2014, pp. 19-24) on the status of regional parties in Spain's contemporary political system, Małgorzata Myśliwiec lists several reasons

conflict as an aberration, a result of a conspiracy against the ideal of building a "world-wide internationalist society of equality and social justice." 
why such parties should be examined. Firstly, they play a key role in the process that Benedict Anderson called the construction of "imagined communities" (Anderson, 1997). Secondly, the significance of such parties has been rising steadily. They have established a presence in nearly every European country. Thirdly, although such parties emerged in Europe in the late 1970s and the early 1980s, they play an increasingly important role in countries of Central and Eastern Europe, especially post 2004. Examples include Bulgaria's Movement for Rights and Freedoms, Slovakia's Party of the Hungarian Coalition, and Poland's Silesian Autonomy Movement. Political scientists describe this phenomenon as the rise of "peripheral nationalisms" (Myśliwiec, 2006). Fourthly, the debate on the rise of regional parties, and in particular, that of a more radical form of ethno-regional parties, should shed light on the consequences of "defreezing" party systems in Central and Eastern Europe. Regionalization has contributed to an overhaul of party systems in that region based on a whole new value system. As a result, next to vertical (hierarchical) system, a growing role is played by horizontal (equality-based) systems (Lijphard, 1977). Fifthly, the emergence of regional parties has forced researchers to redefine the existing criteria for classifying political parties. The need arose to account not only for ideological criteria, but also for collective interests, which their founders commit to protect and enshrine in their charters. One other consequence of the rise of regional movements is the newly-emerged split into central and peripheral parties. As a consequence, many researchers have expanded the classical classification of political parties by adding the new category of regional and ethnic organizations (Beyme, 1982).

In summing up her reflections on the need to study ethno-regional parties, Myśliwiec notes that although many researchers are reluctant to view regional and ethnic parties as a separate theoretical category, the criterion is nevertheless vital for contemporary political science and, as such, should be recognized in examining Europe's party systems. Polish political scientists (Herbut, 2002; Antoszewski, 2009) have expressed reluctance to distinguish ethno-regional parties, which sets them apart from Western European researchers, and especially those who study the British, Italian and, in particular, the Spanish party system.

To structure this article properly, ${ }^{4}$ it is crucial to examine the very essence of regional parties. The British political scientist Derek W. Urwin researched regional parties in the early 1980s. Urwin noted that ever since they first emerged, regional parties were known to pursue a wide range of aims. While their dominant objectives have always been social and economic, there were others that appear to be highly "dangerous" for both the entities they targeted, i.e. "nationalizing states," as well as the players (i.e. parties seeking the fulfillment of such political goals as autonomy and secession). What makes the parties targeting nationalizing states dangerous is that they put territorial integrity and national identity at considerable risk. The risk faced by autonomy seekers lies in the reactions they evoke from the institutions of the states in which they operate. The key characteristic of ethno-regional parties is "the nature of their claims vis-a-vis the state and their approach to voters. The claims aspect concerns the fact that

${ }^{4}$ An analysis of regional and ethno-regional parties has been featured in an article prepared for publication by the author. Its title is European Free Alliance (EFA) as the representative of "unrepresented aspirations." 
regional parties tend to represent the interests of groups whose identity distinguishes them from the overall population of their country. It is also significant that such groups inhabit particular territories. Precisely this specificity, which Urwin refers to as territorial identity, constitutes a common feature of all regional parties. On the other hand, the approach to the voter aspect concerns the fact that regional parties concentrate their electoral activities in their region, which is where they nominate their candidates and where their candidates find their primary support base" (Sobolewska-Myślik, 2012, p. 21). Urwin's proposal comes amidst scores of others formulated in European political science. ${ }^{5}$ A common feature shared by all such proposals is the fact that regional parties emphasize that their political objectives are achieved mainly by operating in their home constituencies, whose cultural, economic and political interests they set out to protect.

Ethno-regional parties are a special case of regional parties. The key difference between regional and ethno-regional parties is that the latter focus their activities on identity issues, which in part defines them as anti-globalization groupings. Such status is derived from the fact that their followers, who emphasize territorial particularism, oppose unification in any form, regardless of whether it concerns the nation-state of which a given region is a part or unification in a global sense. Research on ethnoregional issues is done chiefly by $\mathrm{H}$. Türsan and L. De Winter (2007). Their concepts rest on the assumption that modern research into political mobilization increasingly relies on "new" actors focusing on issues related to ethnic identity. By and large, the authors bring ethnic identity into the ongoing debate on the criteria applying to the classification of political parties. The reason their renewed interest in ethnic identity is referred to as a renaissance is that the issue has been Europe's experience - with more or less intensity - ever since the mid- $19^{\text {th }}$ century, fueling isolationist tendencies at the expense of openness to resolving the internal and external problems of nation-states by joining supranational structures. It is appropriate at this stage of the discussion to cite the definition of the ethno-regional party. The definitions proposed by De Winter and Türsan are discussed by Katarzyna Sobolewska-Myślik, who suggests that the regional party be seen as "any group whose functioning is based on a collective awareness of being ethnically distinctive and on such a party identifying itself with a clearly defined territory" (ibid., pp. 22-23).

De Winter and Türsan distinguished several types of ethno-regional parties. The basis for the distinction used in this classification was the nature of the demands formulated by such parties' leaders. One such type is the protectionist party. The parties have a unique nature, which they expect their home state to protect. Another type, the autonomous party, expects the nation-state to meet its expectation of achieving regional autonomy. Yet another type, identified by De Winter and Türsan, is the $n a-$ tionalist-federalist party, which wants its home states to become a federation. One other party type described by the authors of this typology is the independence party. Its

${ }^{5}$ Other examples include the contemporary book The Origins and Strengths of Regional Parties by Down Brancati, "British Journal of Political Science" 2008, vol. 38, Issue 1; Regionalist Parties in Western Europe, ed. L. De Winter, H. Türsan, Routledge, London-New York, 2007; E. Roller, P. van Houten, National Parties and Regional Systems in Europe, paper delivered at the 2002 Annual Meeting of the American Political Science Association, Boston, Aug. 29-Sept. 1, 2002. 
members expect state authorities and the international community to recognize their rights to pursue independent politics, which boils down to having the right to separate from an existing state. Finally, the classification of ethno-regional parties features the irredentist party, which seek to have their home region break away from its state and join another region with similar characteristics (e.g. one inhabited by people which the irredentists consider to be part of the community they make up), and located within the boundaries of a state adjacent to that of their own region (De Winter, Türsan, 2007, pp. 205, 207).

In her discussion on the functioning of party systems at the regional level, Katarzyna Sobolewska-Myślik notes that "the emergence at the regional level of a unique partisan rivalry that differs from the rivalry observed at the national level may suggest the existence of two distinct party systems within the political system of a given state" (Sobolewska-Myślik, 2012, p. 32). This may be the case in countries with strong traditions of regions asserting their independence by either seeking territorial autonomy or pursuing secessionist aspirations. For the purposes of examining a situation in which, in addition to rivalry at the national level, there is also regional competition, the ideas of Luciano Bardi and Peter Maira appear to be useful. In their analyses, the two scholars argue that contemporary party systems should be treated as "multidimensional phenomena" differentiated by several criteria (Bardi, Mair, 2008, pp. 147-166). Both researchers agree that the central criterion is that of the division of political parties below the central and specifically at the regional level. At this level, which they refer to as horizontal, political parties compete with each other solely at the regional level, while the party system is comprised of a "set" of parties rather than of their system. Parties coexist but do not engage in significant interactions (conflicts). It is also possible at this level to examine how precisely the party-to-party interactions come about at the regional level. The political system can only be decentralized if the following conditions are met: (a) the nature of the elections; for a regional system to actually exist, choices at this level should be different than those at the national level; (b) the competing players; Bardi and Mair point out that the parties that compete may be different (central and regional) or the same, as long as their political significance and their strength differs at both levels; (c) the electoral strategies employed; the strategies should differ at the central and regional levels due to socio-political divisions that occur at these levels and are important to voters (Sobolewska-Myślik, 2012, pp. 36-41).

\section{Concluding remarks}

As a research interest for Polish political scientists, regional parties are largely a terra incognita. There are at least two reasons for this, one being that there are no parties of this type, i.e. regional parties and specifically their particular form of ethnoregional parties, for researchers to study. Secondly, it is difficult to imagine a political program aimed at achieving regional autonomy to emerge in the foreseeable future that could drum up significant support. This does not mean, however, that Poland has no potential or reasons for the emergence of such parties and demands. The regions with all the right makings to create them include Kashubia (Kaszuby) and Upper Si- 
lesia (Górny Ślqsk). The expectations have already become institutional in the form of Kashëbskô Jednota / the Association of People of Kashubian Nationality, the Silesian Autonomy Movement and organizations associating the German minority. Thus far, the success of these organizations on the regional political scene has been limited, as the majority of Kashubian and Upper Silesian regionalists have been active in national parties, using their "regional agendas" instrumentally.

In view of the above findings, the ideas of Bardi and Mair appear to be particularly useful for analyzing such circumstances as those observed in Upper Silesia. This is especially true considering recent announcements to establish a strictly regional political party in the region. The concepts are an outcome of studies of the party systems in which regional rivalries have had strong traditions (Scotland, Catalonia). It seems that the concept can be readily employed to research the emergence of the regional political scene in Central and Eastern Europe. This applies also to Poland. By all indications, given the potential identified in the country's 2011 National Population and Housing Census, Upper Silesia regionalists have a substantial potential to tap. Considering the resistance of the "nationalizing state" which emerged in Poland after the 2015 elections, the regionalists will be compelled to make another bid to consolidate their electorates. Their first unsuccessful attempt came during the last parliamentary elections in the fall of 2015. The success of any of their future consolidation activities in Upper Silesia will hinge on the response to the consolidation drive from the German community, which constitutes Poland's most powerful ethnic minority in organizational and financial terms. Thus far, the aspirations of Upper Silesian regionalists, who want the Polish state to recognize the Silesians as a nationality and their godka (i.e. the language used by native Upper Silesians) as a regional language, have been contested by German minority leaders, and especially those based in the Opole Region. However, the fact that the pressures from the nationalizing state have also been experienced by German minority organizations, may sway Upper Silesian Germans to engage in such activities.

In reply to the question implied in the title of this article and to the theses formulated in its introduction, one must state that the aspiration to create "stateless nations," which the founders of regional parties have written into their electoral programs, may well be propelled by the opportunities presenting themselves in the new transnational order designed by Keating. In its essence, the order brings diversity and a division of sovereignty (between the nation-state and the EU institutions). In addition, the opportunities offered to regions by European integration are both symbolic (becoming part of a community based on values shared across Europe and upheld by other members of the western civilization) as well as practical, described as a set of measures (structural policy measures) and instruments (EU legislation).

\section{Bibliography}

Anderson B. (1997), Wspólnoty wyobrażone. Rozważania o źródlach i rozprzestrzenianiu się nacjonalizmu, Kraków-Warszawa.

Antoszewski A. (2009), Partie i systemy partyjne państw Unii Europejskiej na przełomie wieków, Toruń. 
Altermatt U. (1988), Sarajewo przestrzega: Euronacjonalizm w Europie, Kraków.

Bardi L., Mair P. (2008) The Parameters of Party Systems, "Party Politics", vol. 14, no. 2.

Beyme (von) K. (1984), Parteien in westlichen Demokratien, München-Zürich.

Brubaker R. G. (1998), Nacjonalizm inaczej. Struktura narodowa i kwestie narodowe w nowej Europie, Warszawa-Kraków.

Jaskiernia J. (2014), Autonomia terytorialna w świetle systemu aksjologicznego Rady Europy, in: Autonomia terytorialna w perspektywie europejskiej, vol. I: Teoria-Historia, eds. M. Domagała, J. Iwanek, Toruń.

De Winter L., Türsan H. (2007), Regionalist Parties in Western Europe, Routledge, London-New York.

Geremek B. (2003), Europa stu flag, "Wprost”, vol. 1035.

Herbut R. (2002), Teoria i praktyka funkcjonowania partii politycznych, Wrocław.

Marzęcka B. (2012), Europejska Karta Samorzadu Lokalnego, http://uniaeuropejska.org/europejskakarta-samorzadu-lokalnego/, August 1, 2017.

Iwanek J. (2014), Pojęcie autonomii terytorialnej we współczesnej europejskiej przestrzeni demokratycznej, in: Autonomia terytorialna w perspektywie europejskiej, vol. I: Teoria-Historia, eds. M. Domagała, J. Iwanek, Toruń.

Konarski W. (2014), Autonomia czy secesja? Ruchy regionalistyczne jako forma nacjonalizmu we wspótczesnej Europie i ich możliwy wpływ na ideę zjednoczonej Europy, in: Autonomia terytorialna w perspektywie europejskiej, vol. I: Teoria-Historia, eds. M. Domagała, J. Iwanek, Toruń.

Keating M. (1998), The New Regionalism in Western Union: Territorial Restructuring and Political Change, London.

Lijphard A. (1977), Democracy in Plural Societies: A Comparative Exploration, New Haven.

Myśliwiec M. (2006), Katalonia na drodze do niepodlegtości?, Bytom.

Myśliwiec M. (2014), Pozycja partii regionalnych w systemie politycznym współczesnej Hiszpanii, Katowice.

Sobolewska-Myślik K. (2012), Partie i systemy partyjne na poziomie regionu. Przykład Szkocji i Katalonii, Kraków.

Statute of the Council of Europe, adopted at London, May 5, 1949, Official Journal 1994, No. 118, Item 565.

\section{Summary}

In the article, the author seeks to find what role regional parties should and can perform in the process of European integration. The significance of this question stems from the fact that regional parties tend to face reluctance from the political authorities and societies of "nationalizing states." In the introduction, the author shows how approach to regionalism changed in Europe in the mid-1980s, most prominently in the concept of "new regionalism." He continues to describe the ongoing debate on what regional parties and their particular form, ethno-regional parties, are and the roles they perform in the political systems of contemporary European states. An example is also provided of the political rivalry in the region and the general principles governing competition at the region level. The author believes that the insights into the functioning of regional party systems can be useful in analyzing socio-political processes, especially in Upper Silesia.

Key words: regionalism, new regionalism, territorial autonomy, regional parties, ethno-regional parties 


\section{Miejsce partii etnoregionalnych w procesie integracji europejskiej. Dystraktor czy katalizator}

\section{Streszczenie}

W artykule autor stara się ustalić, jaką rolę powinny i mogą odgrywać partie regionalne procesie integracji europejskiej. Znaczenie tego pytania wynika $\mathrm{z}$ faktu, że partie regionalne spotykają się z niechęcią ze strony władz politycznych i społeczeństw „państw narodowych” We wstępie autor pokazuje, w jaki sposób zmieniło się podejście do regionalizmu w Europie w połowie lat 80 . XX w. Najbardziej widoczne jest ono w koncepcji „nowego regionalizmu”. Kontynuując swoje rozważania autor opisuje toczącą się debatę na temat tego jaką rolę odgrywają partie regionalne, a zwłaszcza ich szczególna forma jaką są partie etnoregionalne w systemach politycznych współczesnych państw europejskich.

Podano również przykład rywalizacji politycznej w regionie i ogólnych zasad rządzących konkurencją na poziomie regionu. Autor wierzy, że analiza funkcjonowania regionalnych systemów partyjnych może być przydatna w analizowaniu procesów społeczno-politycznych, zwłaszcza na Górnym Śląsku.

Słowa kluczowe: regionalizm, nowy regionalizm, autonomia terytorialna, partie regionalne, partie etnoregionalne. 
